\title{
Universiteit
}

Leiden

The Netherlands

\section{Towards a European Contract Law through Social Dialogue}

Castermans, A.G.

\section{Citation}

Castermans, A. G. (2011). Towards a European Contract Law through Social Dialogue. European Review Of Contract Law, 7(2), 360-368. Retrieved from https://hdl.handle.net/1887/17665

Version: $\quad$ Not Applicable (or Unknown)

License: $\quad$ Leiden University Non-exclusive license

Downloaded from: $\quad$ https://hdl.handle.net/1887/17665

Note: To cite this publication please use the final published version (if applicable). 


\title{
Towards a European Contract Law through Social Dialogue
}

\author{
Alex Geert Castermans*
}

Abstract: Suppose the DCFR would be chosen as an optional instrument, will it make business easier? It will not, because of its various references to national law, both of a private and public law nature. It turns out a perilous undertaking to offer private parties a set of rules, by way of an optional instrument, because it is created quite apart from the national private-law and public-law context and it covers only part of the private-law legal relationship. In every single case such a set of rules must be embedded in the applicable national private and public law. An alternative is explored. A European Self regulatory consultation system could provide a framework for drafting model contracts that are tailored to individual sectors. These models should offer terms and conditions that are considered acceptable throughout Europe, with alternatives for Member States having wider or narrower margins.

Résumé: Est-ce que le commerce serait rendu plus facile si le projet de CCR était choisi comme un instrument optionnel? Il est probable que non, en raison des nombreuses références au droit national, à la fois en droit privé et en droit public. C'est dès lors une promesse périlleuse que d'offrir à des parties privées un ensemble de règles par le biais d'un instrument optionnel, car celui-ci est créé de façon assez séparée des droits privés et publics nationaux, et il couvre seulement une partie des relations juridiques de droit privé. Dans chaque cas particulier, un tel ensemble de règles doit être inséré dans les droits nationaux public et privé applicables. Une autre option est explorée. Un système européen de consultation auto-régulateur pourrait fournir un cadre pour élaborer des modèles de contrats qui soient adaptés aux secteurs particuliers. Ces modèles pourraient offrir des clauses et des conditions considérées comme acceptables à travers toute l'Europe avec des options alternatives pour les États membres ayant des marges plus grandes ou plus étroites.

Zusammenfassung: Würde der DCFR als optionales Instrument gewäblt, so stellt sich die Frage, ob dies den Geschäftsverkehr erleichtern würde. Die Antwort ist negativ, schon wegen der vielfachen Bezugnahme auf nationales Recht, privates oder auch öffentliches. Es ist ein problembehaftetes Unternehmen, Privatrechtssubjekten ein Regelwerk als optionales Intrument zur Verfügung zu stellen, dass unabhängig vom nationalen Kontext im Privatrecht und öffentlichen Recht ist und das nur einen Teil der Privatrechtsbeziehungen wirklich regelt. Solch ein Regelwerk muss dann in jedem Einzelfall in den nationalen Kontext des privaten und des öffentlichen Rechts eingebettet werden. Der Beitrag untersucht eine Alternative. Ein europäisches selbstregulatorisches Konsultationssystem könnte den Rabmen bilden, innerhalb dessen Modellvertragsbedingungen entwickelt werden, die auf spezifische Sektoren zugeschnitten sind. Diese Modellvertragsbedingungen müssten natürlich als für ganz Europa akzeptabel ausgestaltet werden und zudem innerbalb eines weiter oder enger gesteckten Spielraums auch Alternativen seitens der Mitgliedstaaten zulassen.

* Professor of Private Law at Leiden University (The Netherlands). He is a fellow of the Meijers Research Institute and Graduate School and coordinates the research-programme Coherent Private. 


\section{One European law of contracts as a perspective for wine merchants and students}

Suppose you are a wine merchant. The wine trade is largely regulated at the European level. For example, Council Regulation (EC) No. 1234/2007 of 22 October 2007 on the organisation of agricultural markets contains, among many other things, rules for allowing oenological practices and limitations. ${ }^{1}$ These rules have been established in connection with issues like the risk of consumers being misled because of their established expectations and ideas, and it is the purpose of the rules to exclude the risk by furthering information measures. But wine merchants must also have regard to national legislation. Not only may Member States adopt stricter rules on oenological practices. ${ }^{2}$ But also the legal relationship between a wine merchant and his customers is governed by national contract law, designated in their choice of law agreement or by private international law.

Long before these rules were introduced and long before all these different European national jurisdictions had come into being, jurists already wrote about what we may expect of a wine merchant. In the thirteenth century the French jurist Jacques de Revigny wrote in his commentary on the Codex Iustinianus about peasants who sold wine to students. ${ }^{3}$ These peasants knew quite well that the nature of their wine did not permit keeping it beyond Christmas, that after Christmas the wine would not be worth the water it contained. A student who had bought such wine from such a peasant and to whom this fact had not been pointed out, ought not to suffer as a result. The winegrower should have pointed out this characteristic of the wine to him. The text can serve as an illustration of a development which started with the literal interpretation of Roman texts - what does it say - and which eventually led to explaining the differences between different texts and recognizing rules that

1 Council Regulation (EC) No.1234/2007 (Single CMO Regulation), OJEC L 299 of 16.11.2007, 1 .

2 Art. 120d (Stricter rules decided by Member States): Member States may limit or exclude the use of certain oenological practices and provide for more stringent restrictions for wines authorised under Community law produced in their territory with a view to reinforcing the preservation of the essential characteristics of wines with a protected designation of origin or a protected geographical indication and of sparkling wines and liqueur wines. Member States shall communicate those limitations, exclusions and restrictions to the Commission, which shall bring them to the attention of the other Member States. For the Netherlands, see the Regulation of 10 June 2009 of the Commodity Board for Arable Farming containing rules for the preparation, packing and labelling of wine (HPA wine Regulation 2009), based on art 2 of the Regulations governing the joint administration of the Common Agricultural Policy, General Part, art 96 and 98 of the Industrial Organisation Act and art 16(3) of the Decree establishing commodity boards for arable farming.

3 K. Bezemer, What Jacques saw (Frankfurt am Main: Vittorio Klostermann, 1997) 121. 
formed a connection, as it were, between all these cases. ${ }^{4}$ The Codex Iustinianus and the Digests already said in abstract terms that a buyer should not suffer from any fraud on the part of the seller; Revigny provided new arguments and texts for this kind of case, so that we get a picture of the scope of the rule.

It was easy for Revigny, in those days. If local rules did not lead to a solution, then the ius commune would often provide help and certainly in cases of purchase and sale it very often did. The advent of new technologies may have facilitated international trade between wine growers and students, but these same technologies facilitated the emergence of nation states and, consequently, national legal systems. And it is precisely these national legal systems which may impede the international ambitions of our wine merchant and students. One European private law seems an attractive perspective for wine merchants who no longer wish to limit their activities to their own regional market and for students who use the international opportunities offered by e-commerce.

\section{An optional instrument}

A group of present-day Revignys, commissioned by the European Commission, have done an impressive job by distilling one single set of principles, definitions and rules, the Draft Common Frame of Reference, from twentyseven systems of private law, doing so within six years. The result covers major fields of private law - not only contract law but also liability law and even parts of property law. This broad approach was chosen because contract law, so it was reasoned, is not a self-standing area of law, it cannot be considered apart from liability law and property law.

How to progress from here? In the green paper on policy options for progress towards a European Contract Law for consumers and businesses (COM (2010) 348) the European Commission outlines all sorts of policy options for progressing towards a European private law. One of them is the so-called optional instrument, a set of universal, elementary private law rules, which parties having international ambitions should be able to make their choice of law. So that a wine merchant will soon be able to say, both to his suppliers and to his customers: here is my wine, offered for sale under the European rules of private law. The Commission has now ordered preparations for the introduction of such an instrument, which according to reports will be limited to 150 contract law rules.

The question is whether any optional instrument could live up to expectations. I would like to answer this question bearing in mind our wine merchant and

4 K. Bezemer, 'The infrastructure of the Early Ius Commune: The Formation of Regulae, or its Failure', in J.W. Cairns and P.J. du Plessis (ed), The Creation of the Ius Commune, From Casus to Regula (Edinburgh: Edinburgh University Press, 2010) 62. 
students, the same people to whom European Commissioner of Justice Viviane Reding referred when she expressed her expectations:

'I want a Polish, German or Spanish consumer to feel as safe when doing business with an Italian, Finnish or French company online as when they are at home. And I want Europe's small and medium-sized companies to offer their products and services to consumers in other countries without having to become experts in the national contract law systems of all other 26 EU countries. $^{5}$

The green paper slightly tempers expectations. Apparently, it is not to be an instrument that makes knowledge of the laws of the (other) Member States superfluous, but an instrument which is to stand on its own, as far as possible, and which must at the same time operate within a national legal system. Of course this does not mean that the wine merchant must be an expert in the twenty-seven national systems of private law of Europe, but even when choosing the 150 rules of the optional instrument he will still have to take account of those twenty-seven systems. But how can an optional instrument then make things easier for the parties, and not more complicated? Might the Draft Common Frame of Reference, for example, make an effective contribution to our trading?

In order to answer this question I will examine whether, and to what extent, the DCFR depends on directory or mandatory national law. Why? Because the more the optional set of rules refers back to any system or to twenty-seven national law systems, the more difficult it will be to grasp the legal relationship and the more difficult it will therefore be to assess the risks of doing business.

\section{References to national law}

There are various places where the DCFR refers to national law in so many words. While it does not do so in the context of contract law, it does in the context of compensation law, unjust enrichment and property law. The contractual rules of the DCFR frequently refer to law, without the adjective national. In the rules on the binding effect of a contract, for example: a contract is binding on the parties; modification and termination is possible as provided by law. ${ }^{6}$ The DCFR also provides that the terms of a contract may be derived from the express or tacit agreement of the parties, and from the rules of law. The explanatory commentary shows that law can be construed to mean: national law.

5 Http://europa.eu/rapid/pressReleasesAction.do?aged=0\&format=HTML\&guiLangua ge $=$ en\&language $=E N \&$ reference $=I P / 10 / 872$.

6 Art II.-1:103.

7 Art II.-9:101(1). 
'It is not only the present rules which may supply a term in the absence of express regulation in the contract. There may be national or other laws which apply to the contract and which supply a term or terms."

So the DCFR and national law go hand in hand. This need not cause problems as long as the rules of the DCFR are identical to their national counterparts. But of course they are not always so. The authors had to make choices where European systems differ from each other. Suppose the wine merchant has made a delivery to two students. Can he claim payment of the entire purchase price from either, even though they have not agreed anything on the subject? In other words, is their liability joint and several or - as the DCFR puts it solidary? Yes, says the DCFR, for pursuant to article III.-4.103(2) the default rule is that the liability of two or more debtors is solidary. But the DCFR also refers to national law, which in the case of the Netherlands and several other countries provides that where two or more debtors are liable to perform the same obligation, each is liable for an equal part. Or take the case that the wine merchant fails to deliver and the students want him to perform the contract. Under continental law the right to performance comes first as a matter of course, but under English law on the contrary it does not. The DCFR opts for the continental system. Consequently, it is not sufficient for simple contracting parties to merely make the DCFR their choice of law. At subjectmatter level they must choose between the DCFR rules and deviating national rules to which the DCFR refers expressly and as a parallel rule.

In addition to all this, the DCFR also uses the concept of mandatory rules, in contract law even regularly. ${ }^{9}$ It puts party autonomy first - freedom of contract - but subject to any applicable mandatory rules. This includes not only mandatory law contained in the DCFR itself, but also national mandatory law. Even when the wine merchant has chosen the DCFR as optional instrument, he must still have regard to national rules, such as the Dutch rules of the Higher Commodity Board for Arable Farming (Hoofdproductschap Akkerboww) for the preparation, packing and labelling of wine, and to similar rules in the other twenty-six Member States. So with regard to the consequences of violation of these rules, the DCFR refers to the rules themselves insofar as they expressly provide for the consequences, and therefore to national law as well.

8 Volume I, 577. See also the rules on representative authority: representative authority may be granted by the principal or by the law (art II.-6:103(1). The explanatory note refers to national law in so many words (Volume I, 417.) Art II.-6:106, moreover, refers to 'any rule of law'.

9 The DCFR has several more floodgates through which national laws pour in. It regularly refers to statutory provisions, presumably including quality regulations and the like laid down pursuant to statutory provisions. These are not typically civil-law provisions. In the case of contracts for services, for example, the DCFR provides that the tools and materials used for the services must be in conformity with the applicable statutory rules or other binding legal rules (art IV.C.-2:105(1)(b)). 
It will be quite a job for the merchant if the rule in question - or the explanatory commentary - expressly leaves the consequences to be determined according to substantive national civil law.

\section{Interaction between public and private law}

The European and national rules for the wine sector were established to protect private interests. In theory, the persons drafting and elaborating those national rules - usually of a public-law nature - will take account of the nature of the legal relationships between private parties, and therefore of the privatelaw concepts on which wine growers and students have to depend, so as to make clear what will be the consequences for these parties if the public-law regulations are violated. This is a matter of proper drafting, in which the authors must - to a certain extent - strive to achieve coherence and consistency, for the sake of the accessibility and enforceability of the rules.

Violation of the Financial Supervision Act, for example, can be countered by a public-law mechanism of supervision and sanctions, while at the same time the compensation of consumers for the loss they have suffered as a result of any violation of the law has been deliberately left to be regulated by national private law. ${ }^{10}$ In the Netherlands this has resulted in the firm ruling of the Supreme Court that the precontractual duty of care of a financial institution can extend beyond its obligations under the Financial Supervision Art. ${ }^{11}$ Conversely, the Netherlands Competition Authority for example is drawing up guidelines for assessing termination rules in the energy sector using privatelaw concepts. ${ }^{12}$

However that may be, public and private rules do interlock, sometimes intentionally, sometimes unintentionally. It is therefore a perilous undertaking to offer private parties a set of rules, by way of an optional instrument, which covers only part of the private-law legal relationship and was created quite apart from the national private-law and public-law context. In every single case such a set of rules must be embedded in the applicable national private and public law. ${ }^{13}$ The outcome of this process is not certain in advance. Consequently, the wine merchant who chooses an optional instrument on the recommendation of the European Commission, does not know what he is choosing, either in the context of his own national law or in the context of the law of

10 Parliamentary Papers II 2005/06, 29 708, no 19, 393-394.

11 HR 5 June 2009, LJN BH2815; De Treek/Dexia.

12 See the decision of the Board of the Netherlands Competition Authority of 16 January 2008 (Guidelines Reasonable Termination Fees Licence Holders).

13 For private law see J. Cartwright, 'Choice is good, Really?' Secola conference, Leuven 15 January 2011. 
any of the other 26 Member States which applies to the legal relationship with his customers pursuant to its conflict of laws rules.

So the DCFR is not the ideal optional instrument. What, then, can the European Commission do for wine merchants wishing to engage in cross-border trade, and for students who so easily get their things from remote suppliers?

\section{Social dialogue}

It could seek inspiration in the Dutch polder, from the work of the Dutch Social and Economic Council (SER) whose Self regulatory consultation Coordination Group offers employers' and consumers' organisations an open framework for consultation on well-balanced General Terms and Conditions. ${ }^{14}$ A Consultation Group has been set up for each branch of business, supported by the SER secretariat. Rights and obligations of entrepreneurs and consumers are geared to the specific characteristics of the branch of business while working out the statutory provisions on consumer terms and conditions as specifically as possible. And a system of low-threshold, private dispute resolution has been set up.

This could serve as a model for a European Self regulatory consultation system, or Social Dialogue, providing a framework for drafting model contracts that are tailored to individual sectors - with terms and conditions considered acceptable throughout Europe, or virtually throughout Europe, with alternatives for Member States having wider or narrower margins. The DCFR could serve as auxiliary law, as did the ius commune studied by Revigny, as a source of inspiration for making choices where the national systems leave parties a choice. This might really serve the parties' interests, because they can rely on the assumption that the document can be used anywhere, while choices to be made at the national level have been identified in advance. This is what the European Commission could facilitate: commission an international group of legal practitioners to draw up these documents and assess on a regular basis which set of rules passes muster by this criterion, for each individual branch of business, for each individual country.

The documents drawn up within this setting could serve as a basis for national and international contracts, contracts which safeguard autonomy and will at the same time come to contribute to convergence of our private-law systems, starting with the law of contracts. The advantage would be that parties would not each time have to ask for directions to find their way through the jungle of rules applying in states and business sectors, while choosing a national private-

14 ww.stvda.nl/sitecore/content/internet/nl/raad/commissies/consumentenaangelegenhed en/zelfreguleringsoverleg.aspx. 
law system will set up better conditions for coordination with and embodiment in the national systems as long as the European Union continues to have twenty-seven different systems of private law, criminal law and public law.

Last year, European Commissioner Reding talked about the realisation of a European Law Institute - on which the same civil-law experts are working that created the DCFR with such expedition - and she said that - for the purposes of achieving a European legal culture - she also attached importance to networks that support practitioners who help citizens and businesses on a daily basis to understand the EU and its rules, and its common principles". ${ }^{15}$ Social Dialogue would be a fine task for such a network.

15 Europa.eu/rapid/pressReleasesAction.do?reference=SPEECH/10/154\&format=HTM L\&aged $=1 \&$ language $=E N \&$ guiLanguage $=e n$. 